\title{
On the rationality of Manx crabs
}

Tove Ahlbom

University of Gothenburg

Sweden

tove.ahlbom@gmail.com

\begin{abstract}
This paper accepts the challenge posed by Godfrey Baldacchino in "Islands and despots", published in Commonwealth \& Comparative Politics in February 2012, to acknowledge and investigate the implications of the "expressions of harmony and solidarity" often observed in small island societies. To do so, aspects of the Isle of Man's political and social life are discussed from the perspectives of popular rule and rationality. This paper argues that a homogeneity in preferences and the political practices of small island states might be a rational way of protecting a vulnerable economy and thus ensuring economic growth and a sufficient allocation to each island resident of the scarce resources required to survive. Such small island homogeneity and consensualism is therefore not necessarily indicating a deficient democratic practice, but might just connote another way of conducting democratic governance, spawned from a particular way of living and a particular range of needs.
\end{abstract}

Keywords: economic vulnerability; homogeneity; islands; Isle of Man; popular rule; rationality; small island democracy

(C) 2014 - Institute of Island Studies, University of Prince Edward Island, Canada.

\section{Introduction}

On the Isle of Man, a small island jurisdiction right in the middle of the Irish Sea, there is a saying that people on the island suffer from the Manx crabs syndrome, described by one of the residents as follows:

'Manx Crabs' is the idea that people will tend to criticize both their equals but also anyone that they consider is getting above his [sic] station, and the image comes from, if you're fishing for crabs, and you've caught crabs, and you put them in a bucket, they all try to sort of climb over each other, but by doing that they pull each other down. And so the crabs don't get out. It doesn't matter how hard they work at it, no crab will ever get to the top and climb out of the bucket, and this image is described as being this idea of Manx Crabs, but it's to do with people generally on the Island having a healthy disregard for a class system, it's actually kind of very flat, you don't get hierarchies, or if you do, they don't last for long. At some level, it tracks itself down, the crabs drag everything down (Ahlbom, 2013, p. 24). ${ }^{1}$

\footnotetext{
${ }^{1}$ During 2012, I studied the Isle of Man's political system as part of my thesis, which was a qualitative study of the Manx political system, emphasizing the structure of consensus within parliament and the non-party system. Empirical data was collected through conversational interviews, literature about the Isle of Man's politicoeconomic history, and by direct observations of sittings of the House of Keys and Tynwald.
} 


\section{T. Ahlbom}

It is this kind of attitudinal homogeneity and the apparently active struggle towards it that is discussed in Godfrey Baldacchino's paper "Islands and despots" (2012). The author argues that, even though the democratic institutions and the "getting along" of small island states may seem like paradise from the perspective of an outsider (such as the researchers who have time and time again concluded that "small is democratic"), the societal structures of such small islands may connote "hell for dissidents" (ibid., pp. 112-3). In other words, it might seem desirable and unproblematic to the fishers that none of the crabs they have caught manage to escape their bucket, but for those crabs attempting to climb out in protest of being captured or in fear of their lives, the constant pulling of their fellow bucket inhabitants may indeed be a hellish experience. But what then are the crabs supposed to do? Staying together in the bucket might be the rational choice, if the togetherness is perceived by the crabs as the only way of surviving in the bucket. On a purely hypothetical level, it may therefore be the will of the manifold of the crabs for all to stay in the bucket. What, then, are the premises of such a rationality assumption when questioning the specific variant of democracy and good governance in a bucket-society? The rule by the incumbent government, whether based on a majority or a minority mandate, implies that there are always parliamentary members opposing the government policy. Those parliamentary members are the representatives of a number of individuals in the society, whose wishes will be pushed to the side because the incumbent government is wishing for something else, in much the same way as the crabs trying to climb out of the bucket are dragged back down. Salman Rushdie once wrote that;

[I]n every generation there are a few souls, call them lucky or cursed, who are simply born not belonging, who come into the world semi-detached, if you like, without strong affiliation to family or location or nation or race; ... there may even be millions, billions of such souls, as many non-belongers as belongers, perhaps; that, in sum, the phenomenon may be as 'natural' a manifestation of human nature as its opposite (Rushdie, 1999, pp. 72-73).

In every democracy, dissidents and non-belongers will occur. Whether on a societal or a parliamentary level, the predominant habitat for dissidents will be hell, as they might get what they need for survival but not what they want. This paper aims to argue, using the Isle of Man as an illustrative example, how a small island democracy with a seemingly extensive homogeneity in attitudes on a national level, may be different from the democratic practices of larger countries, however not necessarily being less democratic in the fundamental meaning of the word. It is a largely unsubstantiated and most often an implicit assumption that democratic government is inherently founded on dissent and opposition, and that democratic practices and institutions consequentially lose constitutional meaningfulness where and when there is no heterogeneous set of values and preferences - represented by a large number of parties (Anckar \& Anckar, 2000) - in a polity. The widespread focus upon competing political parties and contentious voting processes has, for example, been promoted by Schumpeter (2010, pp. 226241), who has argued that the imperfectness of human rationality calls not for emphasis upon the (according to him non-existing) classical democracy doctrine of "the will of the people" but upon the act of selecting representatives. The power of this frame of mind is not surprising considering that the modern world consists mainly of large-scale representative democracies. In this paper, I advocate the importance of noting that democracy is not inevitably connected to diametrical heterogeneity in preferences and an organizational need for representative government as opposed to participatory government (e.g. Pitkin 2004), especially when 
studying small islands. Nor are attitudes inevitably interconnected to preferences. The Schumpeterian frame of mind, which I will refer to as the democracy assumption, is problematized and partly questioned in this paper by introducing a rationality assumption.

\section{Isle of Man politics}

The politics of the Isle of Man do, in many ways, converge with the concerns of Baldacchino (2012). The political system is characterized by an underlying consensus and an absence of party politics (Kermode, 2008, pp. 193-8). In this case, an underlying consensus implies that there is no organized opposition in parliament and that politicians are expected to strive for consensus when making decisions. The candidates who stand for election to parliament and to local authorities on the Isle of Man are mostly 'independents' without any party affiliation, even though there are, and have been throughout history, a number of parties offering candidates for election. The consensus in parliament is promoted by a system of executive branch dominance, where the Chief Minister of the executive branch (the Council of Ministers) is chosen by the parliament, Tynwald, as a whole and therefore has an extremely high legitimacy. The constitution also provides for 'a system of responsible government', meaning that the Council of Ministers is responsible to Tynwald; and, even though constitutional legislation empowers Tynwald to force the Council of Ministers to resign with a motion of no confidence, it also gives the Council of Ministers the 'position of collective leadership'. This constitutional position makes the Council of Ministers increasingly anxious to keep a united front (ibid., pp. 214-5), and "[i]n the absence of disciplined parties, this has been a source of considerable strength, making them the best organised group in Tynwald" (ibid.). There is also a system of "block vote", which in short is a procedure where the Council of Ministers ties the members of the House of Keys (the parliament's lower branch) to them via departmental appointments and statutory boards and in that way ensures that a majority of the votes in Tynwald will be cast in line with the Council of Ministers.

The implications of the block vote are many. It creates a political system that resembles a party system, because of the emergence of a government policy. What differentiates the governmental policies of the Isle of Man from the governmental policies in the majority of other countries is the fact that the government policy is created post election. The parliament ends up with a de facto consensus because the best way to make a difference as an elected politician in parliament is to work inside a department as a departmental member, and hope to eventually be made minister. To sum up, there is a variety of independent and party bound candidates to vote for in an Isle of Man election, but through parliamentary practices one sole party is organised post election, within the parliament (Ahlbom, 2013). This unusual approach towards a governmental policy on the Isle of Man is one of the customs frequently debated within parliament (King, 2013, p. 131) as well as by one of the island's many interest groups, the Positive Action Group which advocates an "open, accountable government, rigorous control of public finances, and a fairer society for all" (PAG, 2014). These are, however, democratic values common to most democracy exponents. This paper would like to point out that the rationality for developing a system of this sort could be the economic vulnerability of a small island jurisdiction, rather than the tendencies of small island politics towards despotism per se. Using the Isle of Man case as an example, this paper hopes to shed some light on possible explanations for the design of small island variety of democracy and governance, other than despotic tendencies, homogeneity in attitudes, and the ostracizing of dissidents. 


\section{T. Ahlbom}

\section{Small island democracy and economy}

Dag and Carsten Anckar have, in several publications, tried to explain the political systems of small island states by analysing factors such as British political heritage and plurality in the same manner as Arendt Lijphart does in his classic work, Patterns of Democracy (Lijphart, 1999/2012; Anckar, D., 2000, 2004, 2006, 2007, 2008, 2013a; Anckar, C., 2008; Anckar, \& Anckar 1995, 2000). However, they have not been able to completely explain the institutional choices of small island states by using Lijphart's explanatory hypothesis that it is "the presence or absence of a British political heritage that appears to explain the distribution ... better than any geographical factor" (Lijphart, 1999, p. 250). D. Anckar has stated that "aspects of culture and rationality may be intertwined to an extent that makes an analytical distinction between the two dimensions almost impossible" (Anckar, D., 2008, p. 81). When discussing the correlation between the characteristics of small island democracies and their economies, it is therefore advantageous to use the key concept of "islandness", within which the aspects of culture and rationality are already intertwined. Islandness includes features such as: common problems among islanders connected to the geographic features of an island; "willingness to learn, flexibility and the readiness to adapt" as a consequence of having a vulnerable economy; "minimal social class and status barriers" in order to enhance dynamic learning capacity; a certain kind of nationalism, where the public tend to watch the politicians closely because they link their own identities to that of the state, and where the same kind of strong connection and supervision can also be found in between individuals of the public (Baldacchino, 2005, pp. 3638); small social distance between those governed and those governing (e.g. Hirczy, 1995, pp. 256-259); the ability of individuals to grasp and understand political life; extremely closely knitted social networks; social limits to conflict and a sense of "community" and the absence of a sense of "alienation" in the relationship between individuals and the state apparatus (Richards, 1982, pp. 158-9); however, in a "World War I way", conflicts may escalate because of the many alliances between individuals (Baldacchino 2005, p. 36). It is also worth noting that some island states are archipelagos, and that the level of geographic fragmentation has its effect on the intensity of the islandness features.

In the Isle of Man case, the geography is contiguous and the small internal market and the few natural resources on the island make it profoundly dependent on its largest economic sectors; finance and business (Kermode, 2008, p. 16) to maintain economic growth and standard of living, and this dependency is something that the islanders are aware of. One island inhabitant describes his worries as follows:

The only thing that differentiates us from one of the western islands of Scotland is that we've got finance industry. And, if you took that away, we would be poor in the way that the western islands are poor. [...] people go to the western islands for tourism, people come to the Isle of Man for tourism, but you've got tourism, farming, fishing, and those three sorts of things are the things that we share, and the difference is that we have this finance industry. And of course the question is: what happens if we don't? (Ahlbom, 2013, p. 29).

One could therefore argue that the effective and consensual government of the Isle of Man enables the finance industry to grow, due to the fact that it offers certainty and policy stability when, as a company dealing with the government; what the Chief Minister says will happen most certainly will, and government policy is not likely to change radically when an election is 
held. Thus, some would argue that it is a governmental structure supportive of economic growth and by extension the survival of the small island democracy, with "communities such as Malta, Faroe, and Mann [that] can be differentiated from both the style of national and local politics in the large polities of the world and stand on their own in a specific category" (Richards, 1982, p. 170). The economic implications of island geography (Birch, 1958; Baldacchino, 1993) not only create common problems among the islanders, but also a dynamic society that is ready to adapt and is willing to learn in order to survive economically (Anckar, 1999, p. 30).

S. E. Finer argues, in Lijphart's words, that "macroeconomic management requires not so much a strong hand as a steady one" (Lijphart, 1999, pp. 259-260), and in the extreme economic vulnerability of small island geography, the Isle of Man seems to have constructed, as Richards (1982) has argued, its own political system. Both a strong and steady government are created by using some of the strengthening majoritarian institutions found in the Westminster-style parliament, and allowing the steadiness to occur by enshrining the old consensual traditions of the Viking Tynwald in combination with establishing the sort of "block vote" that has been outlined above.

The relevance of strong and steady government in vulnerable island economies becomes even clearer when indulging in research on the topics of tax havens and small island economies (SIEs). Research conducted by Dhammika and Hines (2009) regarding "which countries become tax havens", suggest that it is small, affluent island economies with high governance qualities that have the best prospects. Hampton (2002) discusses the implications for small island tax havens, and brings to our attention that many SIE's are dependent upon offshore finance, because of the "barriers to diversification arising from their smallness and unique political economies". Hampton also mentions the work of Baldacchino (1993) that reviews the survival strategies of developing micro-economies, where he argues that microstate economies may be successful if they resort to "opportunist pragmatism", such as taking advantage of the possibilities of being partly dependent on a larger economy: "To succeed in development is to perceive and exploit the possibilities and mitigate the obstacles as these emerge, in compliance with the basic formulations of what is understood by development in particular contexts" (ibid., p. 36); in other words, to be dynamic and always ready to make the most economically efficient decisions.

\section{Assumptions of democracy and rationality}

When you have no picture of the world, you don't know how to make choices material, inconsequential or moral. You don't know which way is up, or if you're coming or going, or how many beans make five (Rushdie, 1999, p. 487).

Historically, ideas on what is small and what is democratic have of course altered. As Dahl and Tufte (1973, p. 1) write: "to an Athenian democrat at the time of Pericles, the Netherlands - a 'small country' - would seem a gigantic empire, fit only for despotic emperors and slavish citizens". The classic representative democracy doctrine, as presented by Schumpeter, is all about the will of the people and has been largely replaced by scepticism towards the idea of a cohesive will of the people and the successive emphasis on the act of voting (2010, p. 241). However, this distinction between doctrines is merely an organizational one, provided that we embrace the basic definition of democracy as "a practical form of decision-making that derives its normative legitimacy from the degree to which it approaches the ideals on which it is based 


\section{T. Ahlbom}

... [and] derives its sociological legitimacy from the degree to which it works in practice." (Mansbridge et al., 2010, p. 84). As long as the practical dimension of democracy is acknowledged, the variety of democracies in the world becomes easier to understand.

In "Islands and Despots", Baldacchino writes that, in small island states, "[d]emocratic practices and supporting institutions may exist and operate, and a semblance of pluralism will be manifest, but all these are likely to be overshadowed by what Dahl and Tufte ... refer to as a "single code"" (2012, p. 109). The societal situation of a "single code" is one where "norms ... are easily communicated by word and example, violations are visible, sanctions are easy to apply by means of both gross and subtle forms of social interaction, and avoidance of sanctions is difficult" (Dahl \& Tufte, 1973, p. 92). These are features that may have different effects in different contexts, affecting for example prospects of political accountability, prerequisites for consensus, and information costs. If we were to create a contradiction between pluralism and its democratic institutions (formal as well as informal) and the homogeneous society, we would create a base for the above-mentioned democracy assumption; since there is a dominant 'single code' in a society, democratic practices and institutions are unable to foster good governance.

Since most political science research, as mentioned above, focuses on geographically and demographically large states where a single code is less likely to be present, the democracy assumption is more often than not present as well. Students of political science are taught to think of democratic institutions as existing in order to "handle" a range of heterogeneous preferences and attitudes, consequently making democratic institutions worthless and shallow if there are no such heterogeneous prerequisites. I would like to argue that democratic institutions exist in order to enable popular rule, whether or not the people agree on what they want. In the case of the Isle of Man and small island democracies more generally, it seems plausible to argue that the vulnerability of the island economy creates common interests and preferences for the islanders, going above and beyond their attitudes, making the alternative of consensual democracy look like an effective, rational governmental alternative. Hermansson (1984) touches upon this when differentiating between Rousseau's concepts of volonté général (the general will) and volonté de tous (the will of the many). Volonté general can be interpreted as an accumulated preference that is common for all; what has, in this paper, been referred to as "the will of the people". Volonté de tous on the other hand is the aggregated individual preferences of the people (Hermansson 1984, p. 346), which could instead be referred to as attitudes, and this should lead to a discussion of the possibilities of separating individual attitudes from preferences.

I seek to deploy the rationality assumption in order to problematize the democracy assumption as based on Anthony Downs' classical paper An economic theory of political action in a democracy. In Downs' theory, the political action of a certain agent, whether it is an individual or a group of people, is the outcome of rational behaviour; in Downs' words "it proceeds towards its goals with a minimal use of scarce resources and undertakes only those actions for which marginal return exceeds marginal cost" (Downs, 1957, p. 137). The argumentation of this paper is based on the notion that, in a small island democracy such as the Isle of Man, it is possible for a volonté général to form, as well as common goals towards which citizens will proceed in a rational manner. This may be due to the factors associated with islandness, and more specifically to the economic vulnerability that exists as compared to larger economies. This principle is the same as that of Maslow's well-known hierarchy of needs: security of resources trumps and precedes the goals of self-actualization (Maslow, 1943). It is important to bear in mind here that the term 'rational' is synonymous, in economic 
theory, with being 'efficient', and "must not be confused with the logical definition (i.e., pertaining to logical propositions) or the psychological (i.e., calculating or unemotional)" (Downs, 1957, p. 137). When assuming this meaning of the term, "it is always rational to perform any act if its marginal return is larger than its marginal cost" (ibid., p. 146). As this is originally an economic theory, the possible obstacles on an agent's political path comprise any difficulties to obtain information regarding the decision to be taken. The nature of political action will, as a result of this, vary depending on the costs of information in the agent's surroundings.

Downs' economic theory of political action questions the view of democratic politics as a context where the actual outcome of an action also provides the true incentives behind the action (ibid., p. 136). For example, the fact that a government succeeds in providing welfare to its citizens does not necessarily mean that it sought to be elected into office in order to do so; the government is part of the division of labour in the sense that it has "both a private motive and a social function" (ibid.). Politicians are therefore most likely to stand for election motivated by their private interest such as earning an income and power, but while in office they may "nevertheless carry out their functions with great efficiency, at least under certain conditions" (ibid.). In conclusion, Downs' central hypothesis reads as follows,

They [political parties] do not seek to gain office in order to carry out certain preconceived policies or to serve any particular interest groups; rather they formulate policies when in power and serve interest groups in order to gain office. Thus their social function - which is to formulate and carry out policies when in power as the government - is accomplished as a by-product of their private motive - which is to attain the income, power and prestige of being in office ... In effect, it [the government] is an entrepreneur selling policies for votes instead of products for money (Downs, 1957, p. 137).

In much the same manner, Downs argue that that the voter (at least in a world of perfect knowledge where information is free) "votes for whatever party he believes would provide him with the highest utility income from government action", based on the previous performances of the party (ibid., p. 138); or, in the Isle of Man case, the individual politician. But, as we all know, there is no such world of perfect knowledge and costless information. This imperfection makes for certain tweaks on the political institutions of a society. In Downs' model, imperfect knowledge means three things: 1) that "parties do not always know exactly what citizens want", 2) that "citizens do not always know what the government or its opposition has done, is doing, or should be doing to serve their interests", and 3) "that the information needed to overcome both types of ignorance is costly - in other words, scarce resources must be used to produce and assimilate it" (ibid., p. 139). The implications of these conditions on political action are, in Downs' model, three: "persuasion, ideologies, and rational ignorance" (ibid.).

In the small island democracy of the Isle of Man, where the ballots are free and fair and citizens may legally organize a party or any other interest group, a rationality perspective on the Manx society's democratic workings puts it in a much more sympathetic light. Firstly, the individual Manx citizen is probably less omitted to persuasion than a citizen of a larger, mainland democracy. Factors of islandness and smallness, such as close social networks and a "politically savvy public" (e.g. Baldacchino, 2005a; 2012; Hirczy 1995; Richards, 1982), make the path from need to political action less covered with information costs by making it easier 


\section{T. Ahlbom}

for citizens to know "what the government is doing, and what other parties would do if they were in power" (Downs, 1957, p. 139). The higher the costs for finding out "what is happening to them or what would happen to them if another party were in power" (ibid. 140), the higher the risk for persuaders to provide biased information in order to secure their own personal interests (ibid.). If person A can persuade person B to vote in line with person A's personal interests due to person B having trouble getting information enough to know what will benefit him or her the most, person A becomes more politically important than person B because person A can influence more votes than he or she can cast in the free and fair ballots. Because the rational government is selling policies for votes, it becomes more important for the government to adapt its policies to person A's than to person B's needs, creating political inequality because; "[i]n fact, it is irrational for a democratic government to treats its citizens with equal deference in a world in which knowledge is imperfect" (ibid.).

The above mentioned factors of islandness and smallness not only enable citizens to know their government and the government's actions; it also enables the government to know its citizens' needs and preferences. Lack of information going from the public to the government forces the government to decentralize by means of representatives "until the marginal vote-gain from greater conformity to popular desires is equal to the marginal voteloss caused by reduced ability to co-ordinate its actions" (ibid.). The government's representatives, the link between those governed and those governing are also in position where they have huge possibilities to persuade voters to align their interests with their own, a decentralized democracy will therefore be more politically unequal (ibid.).

The lack of a strong party system on the Isle of Man can also be explained by the rationality assumption, arguing that it is an outcome of low initial information costs rather than the oppression of opposition building, because ideologies are merely a way of reducing information costs for voters. In a large, complex society, this is needed because "the cost in time alone of comparing all the ways in which the policies of competing parties differ is staggering" (ibid., p. 141). If there is a clear correlation between a party's ideology and its policies, the voter's path to a rational decision is simplified by the shortcut of ideology (ibid., p. 142). The relative lack of political ideologies on the Isle of Man would, with this reasoning, make for a stable government, no matter how many parties exist. Attitudinal homogeneity in small island states and territories, reported by many (e.g. Baldacchino, 2005a, 2012; Anckar, 1999, 2004, 2008; Anckar \& Anckar, 1995; Dahl \& Tufte, 1973; Richards, 1982), implies that the vast majority of the voters would agree on political matters. Because the government follows the "nature of the distribution of voters along the left-right scale" (Downs, 1957, p. 145) in designing policies, a polity with a high degree of attitudinal (or preferential) homogeneity where a large proportion of the voters are situated "within a narrow range of that scale" (ibid.) will be getting a government with more effective and well-integrated policy-sets, and a higher ability to solve social problems (ibid., pp. 144, 145) and pursue economic growth, as mentioned above (Lijphart, 1999, pp. 259-260). The initially low information costs stemming from the smallness of the society and the close social networks creates a political arena which is rationally possible for the citizens to grasp and understand (Dahl \& Tufte, 1973, p. 15). The mere opportunity to explore a bigger set of alternatives does however not necessarily mean that citizens will explore those alternatives, as Lupia and McCubbins (1998, p. 6) put it: "ignoring useless information is necessary for humans and other species to survive and prosper". It is the marginal gain of exploring the alternatives that has to exceed the marginal cost, and the costs are likely to be higher in a larger democracy. The outcomes of 
citizens' more or less rational decisions may then very well be the same ones in a small democracy as in a large one. If one would feel the urge to make a normative statement on the subject, it would therefore have to be about which decision making process is the most desirable: one where there is a small number of alternatives and the citizen knows them all, or where there is a large number of alternatives and the citizen knows a limited selection of them.

Political action, when it comes to the Isle of Man's political scene, can be seen as both the introduction and subsequent use of ministerial government and the block vote in parliament and the homogeneity in attitudes, postulating that it is this homogeneity in attitudes that legitimizes the political actions of the government through free and secret ballots. The Isle of Man differs from the majority of democracies in the world not only because of its unique parliamentary system but also because of its lack of political parties. There is a striking absence of party culture on the Isle of Man and the electoral campaigns are indeed based on the personalities and social networks of the candidates. However, there are no restrictions or prohibitions towards political parties; they just don't succeed in gaining parliamentary representation (Ahlbom 2013). This is the case in a number of other small island democracies as well, such as Jersey (Jersey Evening Post, 2008), Guernsey (States of Guernsey website), the Marshall Islands, Kiribati, and Nauru (Anckar \& Anckar 2000, pp. 239-240).

\section{Conclusion}

This paper is loosely based on a case study of the Isle of Man, a self-governing sub-national island jurisdiction. The oppositions towards case studies are many (see for example Anckar 2013 b, p. 16), one of the main arguments being that "you cannot generalize from a single case" (Flyvbjerg 2006, p. 219). This very valid argument is one of the reasons that this paper aims to contribute with an additional perspective to the discussion about democracy in small island states and societies, rather than generating generalizable knowledge. As a matter of fact, democratic governance at the sub-national level where we can find jurisdictions such as the British Crown Dependencies of Jersey, Guernsey and the Isle of Man has been scarcely researched and academic discussion about their democracy and governance is limited. Future researchers that would like to study how and where democracy can be brought about have a huge asset in the small island democracies around the world, and a challenging task in trying to show evidence of or reject that, under certain conditions, it could be rational and possible to cooperate by changing preference without changing attitudes.

Rational choice theory, the idea of rational individuals rejected by Schumpeter and used in this paper, is known for being an ideal model. This means that theoretical reasoning is taking place within a model world where information is perfect. In this world, individuals are able to act rationally since they have all the information they need in order to do so. Thus, the only intrinsic claim of rational choice theory is that its predictions will be better the closer the real world is to the model world. Considering this, there wouldn't necessarily have to be a contradiction between Schumpeterian party-competitive electoral democracy and a non-party consensual democracy. As Pitkin (2004, p. 337) puts it, "It is a matter of degree, an idea or ideal realized more or less well in various circumstances, conditions, and institutional arrangements". Because of the extreme expense of getting informed in large political settings when making political decisions, shortcuts toward this information are being used. Such a shortcut could be relying on the manifestos of parties and the solidity of representatives, thus recognizing large scale representative democracy in large countries as rational without it connoting irrationality in other systems, such as the Isle of Man. In an attempt to be 


\section{T. Ahlbom}

overwhelmingly diplomatic, one could argue that since our everyday life does not take place in a model world, but a world of imperfect information, states and individuals create structures within which they act in order to overcome information costs. The relative cost of information is therefore likely to shape the structures of political action.

The political society of the Isle of Man is in many ways a flat one; hierarchies dragged down by the Manx Crabs Syndrome, the members of the bucket society inevitably codependent. "In such places [small islands], differences among individuals are often ignored, and a confining sense of geographical limits reduces the interpersonal friction", argues Dag Anckar (1999, p. 41). Is this ignorance necessarily a bad thing? Is this an acceptance of differences or an attempt to eliminate them? Is this hell for dissidents or the nature of small island societies because "you cannot, in a community this size, ignore people; you can't ignore them! You bump into them!" (Ahlbom 2013, p. 25), as an Isle of Man resident explains? If you cannot ignore a person because you are stuck together on a small island in the Irish Sea, or any other sea for that matter, you may actually benefit from disregarding the attitudinal differences between the two of you and focus on your mutual preferences rather than programmatically dissociate oneself from the other. The social climate of small island states or jurisdictions is not always pleasant for everyone, nor is every homogenous small island state, a small island jurisdiction or a bucket of Manx crabs by definition a well-functioning democracy. Yet, homogeneity is not inherently contradictory to rationality and democratic government, but might actually be an advantage within a specific institutional framework.

\section{Acknowledgements}

The author thanks Urban Strandberg at the University of Gothenburg, Sweden, for extremely helpful critical reviews and advice during the writing of this paper, two anonymous reviewers, and my Isle of Man friends and family for inspiring me to write it in the first place.

\section{References}

Ahlbom, T. (2013). Size matters: a case study of small island democracy on the Isle of Man. (Bachelor thesis in Political Science, University of Gothenburg, Sweden). Manx National Heritage manuscript collection deposit no. MS 13296.

Anckar, D. (1999). Homogeneity and smallness: Dahl and Tufte revisited. Scandinavian Political Studies, 22(1), pp. 29-44.

Anckar, D. (2000). Westminster democracy: a comparison of small island states varieties in the Pacific and the Caribbean. Pacific Studies. 23(3-4), pp. 57-76.

Anckar, D. (2004). Direct democracy in microstates and small island states. World Development. 32(2), pp. 379-390.

Anckar, D. (2006). Islandness or smallness? A comparative look at political institutions in small island states. Island Studies Journal. 1(1), pp. 43-54.

Anckar, D. (2007). Westminster lilliputs? Parliaments in former small British colonies. Parliamentary Affairs, 60(4), pp. 637-654.

Anckar, D. (2008). Microstate democracy: majority or consensus: diffusion or problemsolving? Democratization, 15(1), pp. 67-85. 
Anckar, D. (2013a). Legislatures in the Pacific islands. In N. D. J. Baldwin (Ed.) Legislatures of small states (pp. 35-43). London: Routledge.

Anckar, D. (2013b). Legislature in small polities. In N. D. J. Baldwin (Ed.) Legislatures of small states (pp. 12-19). London: Routledge.

Anckar, C. (2008). Size, islandness and democracy: a global comparison. International Political Science Review, 29(4), pp. 433-459.

Anckar, C., \& Anckar, D. (1995). Size, insularity and democracy. Scandinavian Political Studies, 18(4), pp. 211-228.

Anckar, C., \& Anckar, D. (2000). Democracies without parties. Comparative Political Studies, 33(2), pp. 225-247.

Baldacchino, G. (1993). Bursting the bubble: the pseudo-development strategies of microstates. Development and Change, 24(1), pp. 29-51.

Baldacchino, G. (2012). Islands and despots. Commonwealth \& Comparative Politics, 50(1), pp. $103-120$.

Baldacchino, G. (2005). The contribution of 'social capital' to economic growth: lessons from island jurisdictions, The Round Table: Commonwealth Journal of International Affairs, 94(1), pp. 31-46.

Birch, J. W. (1958). Economic geography of the Isle of Man, The Geographical Journal, 124(4), pp. 494-510.

Dahl, R. A. (1966). Further reflections on 'The elitist theory of democracy'. American Political Science Review, 60(2), pp. 296-305.

Dahl, R. A., \& Tufte, E. (1973). Size and democracy. Stanford CA: Stanford University Press.

Dhammika, D., \& Hines, J. R. (2009). Which countries become tax havens? Journal of Public Economics, 93(9-10), pp. 1058-1068.

Downs, A. (1957). An economic theory of political action. Journal of Political Economy, 65(2), pp. 135-150.

Flyvbjerg, B. (2006). Five misunderstandings about case-study research. Qualitiative Inquiry, $12(2)$, pp. 219-245.

Hampton, M. P. (2002). Offshore pariahs? Small island economies, tax havens, and the reconfiguration of global finance. World Development, 30(9), pp. 1657-1673.

Hermansson, J. (1984). Modern rationalistisk teoribildning och Rousseaus teori om allmänviljan. Statsvetenskaplig tidskrift, 87(4), pp. 343-350.

Hirczy, W. (1995). Explaining near-universal turnout: the case of Malta. European Journal of Political Research, 27(2), pp. 255-272.

Jersey Evening Post (2008). Election 2008: St Helier No. 2, retrieved from http://jerseyeveningpost.com/election/deputies/st-helier-no-2/, 2014-02-27.

Kermode, D. (2008). Ministerial government on the Isle of Man. Douglas: Manx Heritage Foundation.

King, J. (2013). The Isle of Man: Tynwald. In N. D. J. Baldwin (Ed.) Legislatures of small states (pp. 122-133). London: Routledge.

Lijphart, A. (1999/2012). Patterns of democracy: Government forms and performance in thirty-six countries. New Haven CT: Yale University Press.

Lupia, A., \& McCubbins, M. (1998). The democratic dilemma: Can citizens learn what they need to know? Cambridge, MA: Cambridge University Press. 
Mansbridge, J., Bohman, J., Chambers, S., Estlund, D., Føllesdal, A., Fung, A, Lafont, C., Manin, B., \& Martí, J.-L. (2010). The place of self interest and the role of power in deliberative democracy. The Journal of Political Philosophy, 18(1), pp. 64-100.

Maslow, A. H. (1943). A theory of human motivation. Psychological Review, 50(4), pp. 370396.

PAG. (2014). Positive Action Group - Possan Jantys Jarrooagh. Retrieved from http://www.positiveactiongroup.org/

Pitkin, H. F. (2004). Representation and democracy: uneasy alliance. Scandinavian Political Studies, 27(3), pp. 335-342.

Richards, J. (1982). Politics in small independent communities: conflict or consensus? The Journal of Commonwealth \& Comparative Politics, 20(2), pp. 155-171.

Rushdie, S. (1999). The ground beneath her feet. London: QDP.

Sartori, G. (1976). Parties and party systems: A framework for analysis. Cambridge: Cambridge University Press.

Schumpeter, J. A. (2010). Capitalism, socialism and democracy. London: Routledge.

States of Guernsey (2014). Elections 2012, retrieved from http://www.gov.gg/elections, 2014$02-27$. 